\title{
Selection of indexes to evaluate the genetic variability aiming ornamental use of peppers accessions ${ }^{(1)}$
}

\author{
PETTERSON BAPTISTA DA LUZ ${ }^{(2)}$, ALESSANDRO APARECIDO BRITO DOS SANTOS ${ }^{(2)}$, VALDETE CAMPOS \\ AMBROSIO(2), LEONARDA GRILLO NEVES ${ }^{(2)}$, ARMANDO REIS TAVARES ${ }^{(3)}$
}

\begin{abstract}
There are few varieties of commercial peppers for landscape use, although Capsicum germplasm banks in Brazil have accesses that can be used in breeding programs to create new ornamental peppers. The present study aims evaluate the genetic variability of pepper accesses in relation to their ornamental potential by a selection of indices. A total of 55 peppers accessions were used in the germplasm collection of Mato Grosso State University. The heritability of the studied variables showed that all the variables have high heritability. Fruit length and weight showed the highest heritability values with $99.88 \%$ and $99.67 \%$, respectively. The selection based on Summa Rank-Based Index would result in plants with long fruits and peduncles, fruits with higher weight and wider, with leaves and petioles with longer lengths, and a reduction of other characteristics. The Base and the Classical Indexes are significant, as it would result in compact canopy and reduced plants, desired characteristics for ornamental plants. The index based on Summa Rank-Based Index permitted a great gain in pepper selection for ornamental purpose.
\end{abstract}

Key words: Capsicum spp., biometric models, selection gains.

\section{RESUMO}

Índices de seleção na avaliação da variabilidade genética visando ao potencial ornamental de acessos de pimentas O número de variedades de pimentas comerciais destinadas ao paisagismo é reduzido, embora os bancos de germoplasma de Capsicum do país possuam em seu acervo acessos que podem ser utilizados no melhoramento genético para desenvolvimento de novas cultivares de pimentas ornamentais. Objetivo-se avaliar a variabilidade genética visando o potencial ornamental de Acessos de pimentas através de índices de seleção. Foram utilizados 55 acessos de pimenteiras existentes na coleção de germoplasma da Universidade do Estado de Mato Grosso. Observando a herdabilidade das variáveis estudadas pode-se verificar que todas as variáveis apresentaram alta herdabilidade, sendo os maiores valores, de 99,88\% e 99,67\%, para o comprimento do fruto e peso do fruto. A seleção baseado no índice em Soma de Ranks, resulta em plantas com frutos e pedúnculos compridos, frutos com maior media de peso e mais largos, com folhas e pecíolos com maiores médias de comprimento, e com redução nas demais características. Ouso de Índice Base e de Índice Clássico é apreciável, pois resulta em plantas com dossel compacto e porte reduzido, características interessantes para a ornamentação. O Índice baseado na Soma de Ranks permite alcançar um maior ganho de seleção.

Palavras-chave: Capsicum spp., modelos biométricos, ganhos de seleção

\section{INTRODUCTION}

Peppers are mainly used for cooking; however, some peppers of the genus Capsicum are used as ornamental plants. The characteristics that confer aesthetic value for peppers are the variegated foliage, small fruit and, fruits with intense color contrasting with the foliage (CARVALHO et al., 2006), furthermore, are easy to grow and have great durability.

A distinctive factor for a plant be used of ornamental is its capacity to be cultivated in containers as vase plants. Peppers used in landscape have a larger size than those cultivated in containers, especially if the container limit root and aerial growth. Ornamental peppers cultivars are mainly used for decoration, though the fruits can be used to make pickling pepper or be dehydrated (WITT, 1999). The most popular ornamental peppers in Brazil are 'Pirâmide ornamental' $(C$. frutescens) and 'Calypso' (C. annuum) and there are a small number of others cultivars such as 'Sangria', 'Cajun belle', 'Purple flash', 'Black pearl', 'Black olive' 'Garda tricolore', 'Numex centennial'(PINTO et al., 2010). The Isla Company has four ornamental peppers: Hot Pepper Etna, Pyramid, Hot Pepper Stromboli Ornamental and Hot Pepper Octopus in the Brazilian market and released the new varieties Etna and Stromboli in 2017 (ISLA, 2018).

There are few commercial varieties for landscape use, although the Capsicum germplasm banks in Brazil have accesses that can be used for genetic improvement of new ornamental peppers (WITT, 1999; NEITZKE et al., 2010). Sudré et al. (2005) used multivariate techniques to study the genetic distance of 56 pepper accesses from the Capsicum germplasm collection of the Norte Fluminense State

DOI: http://dx.doi.org/10.14295/oh.v24i1.1109

(1) Received in 19/07/2017 and accepted in 20/02/2018

(2) Universidade do Estado de Mato Grosso (UNEMAT), Cáceres-MT, Brazil. *Corresponding author: petterbaptista@yahoo.com.br

(3) Instituto de Botânica (IBt), São Paulo-SP, Brazil.

Licensed by CC BY 4.0 
University, and suggested some accesses for ornamental use. Embrapa Clima Temperado maintainan Active Bank of Capsicum Germplasm, which conserves accesses of C. annuum, C. baccatum, C. chinense, C. frutescens and C. pubescens, since 2003. Morphological characteristics as size, type of flower (or inflorescence), color and shape of fruits and leaves, suitable for vase cultivation for interior decoration have to be considered in order to select species with ornamental potential (Santos et al., 2015).The information available about the accesses maintained in germplasm banks is directly linked to their use in breeding programs and by rural communities. The morpho-agronomic studies and genotypic and phenotypic divergences are the main fonts of information, which allows the uses of the accesses (BIANCHI et al., 2016).

In the presented context, this study aimed to evaluate the genetic variability of Capsicum spp. ornamental potential using selection indexes.

\section{MATERIAL AND METHODS}

The 55 Capsicum spp. accessions were cultivated at UNEMAT germplasm collection (Table 1).

Table 1. Name of Capsicum spp. accesses of the UNEMAT collection.

\begin{tabular}{|c|c|c|}
\hline Access Names & Access Names & Access Names \\
\hline UNEMAT 1 & UNEMAT 20 & UNEMAT 39 \\
\hline UNEMAT 2 & UNEMAT 21 & UNEMAT 40 \\
\hline UNEMAT 3 & UNEMAT 22 & UNEMAT 41 \\
\hline UNEMAT 4 & UNEMAT 23 & UNEMAT 42 \\
\hline UNEMAT 5 & UNEMAT 24 & UNEMAT 43 \\
\hline UNEMAT 6 & UNEMAT 25 & UNEMAT 44 \\
\hline UNEMAT 7 & UNEMAT 26 & UNEMAT 45 \\
\hline UNEMAT 8 & UNEMAT 27 & UNEMAT 46 \\
\hline UNEMAT 9 & UNEMAT 28 & UNEMAT 47 \\
\hline UNEMAT 10 & UNEMAT 29 & UNEMAT 48 \\
\hline UNEMAT 11 & UNEMAT 30 & UNEMAT 49 \\
\hline UNEMAT 12 & UNEMAT 31 & UNEMAT 50 \\
\hline UNEMAT 13 & UNEMAT 32 & UNEMAT 51 \\
\hline UNEMAT 14 & UNEMAT 33 & UNEMAT 52 \\
\hline UNEMAT 15 & UNEMAT 34 & UNEMAT 53 \\
\hline UNEMAT 16 & UNEMAT 35 & UNEMAT 54 \\
\hline UNEMAT 17 & UNEMAT 36 & UNEMAT 55 \\
\hline UNEMAT 18 & UNEMAT 37 & \\
\hline UNEMAT 19 & UNEMAT 38 & \\
\hline
\end{tabular}

The seeds of Capsicum spp. accessions were sown in polystyrene trays with 128 cells containing the commercial substrate Plantimax ${ }^{\circledR}$. The accessions were cultivated in a greenhouse. After 46 days, seedlings with four to six definitive leaves and about $10 \mathrm{~cm}$ high were transferred to the field. The cultural practices to cultivate the plants during the experimentation were carried out as recommended by Filgueira (2005).

The morpho-agronomic characterization of the accessions was carried out considering different parts of the plant. The analyses started as $50 \%$ or more of the plants in the plot had fruits. The descriptors used for Capsicum genus were proposed by IPGRI (1995) and as recommended by Neitzkeet al. (2010) in order to efficiently achieve the data. Eleven quantitative descriptors were used to quantify the genetic variability of the accessions and they were evaluated based on the averages of the following variables: 1) Plant height $(\mathrm{cm})$ measured from the base of the plant to the highest point of the crown $(50 \%$ of the plants with mature fruits), 2) Shoot width (cm); 3) Shoot length $(\mathrm{cm})$; 4) Shoot area $\left(\mathrm{m}^{2}\right)$, Shoot width multiplied by Shoot length. Fruits characteristics evaluated: 5) Fruit length (cm); 6) Fruit diameter; 7) Fruit weight (fresh mass, g); 8) Length of fruit peduncle. Data from 30 mature fruits random selected were used to evaluate fruit length, fruit diameter, fruit weight and length of fruit peduncle. Leaf characteristics evaluated: 9) leaf length; 10) leaf width and 11) length of the petiole.

The indexes used in the study were: 1. Classic Index method - proposed by Smith (1936) and HAZEL (1943) (SH); 2. Index-based Desired Earnings method (PESEK and BAKER, 1969); 3. Base index proposed by Willians (1962) (WB); and 4. Summa Rank-Based Index method (MULAMBA and MOCK, 1978).

The experimental design was the randomized blocks (DBC), three blocks, with three plants in each plot. The statistical analyses were performed using the software GENES (CRUZ, 2010). 


\section{RESULTS AND DISCUSSION}

All variables presented high heritability (Table 2), with highest values of $99.88 \%$ for fruit length and $99.67 \%$ for fruit weight. The lowest heritability values were $89.12 \%$ for shoot length and $92.66 \%$ for shoot width. These results are indicative of a possible genetic gain with the selection and the wide genetic variability among accessions studied. Soares et al. (2017) estimated the genetic parameters for characters related to fruit production and quality of pepper. The authors observed a wide genetic variability, which was evidenced by the high coefficients of heritability, ranging from $52.6 \%$ to $83.2 \%$.

Table 2. Estimative of heritability percentage $\left(\mathrm{h}^{2 \%}\right)$ and percentage gains with selection (Gs\%) of 55 accessions of peppers, of the characteristics: fruit diameter, fruit length, length of fruit peduncle, fruit weight, leaf petiole, leaf width, leaf length, plant height, shoot length, shoot width and shoot area.

\begin{tabular}{|c|c|c|c|c|c|}
\hline VARIÁVEL & IBW & IBGDPB & $\begin{array}{c}\text { ICSH } \\
\text { GS } \%\end{array}$ & $\begin{array}{c}\text { IBSRMM } \\
\text { GS } \%\end{array}$ \\
\hline Fruit Diameter & GS $\%$ & 14.39 & -6.02 & 1.34 \\
\hline Fruit lenght & 98.64 & -6.02 & -18.34 & 123.17 & 125.36 \\
\hline Length of fruit peduncle & 99.88 & 123.17 & 8.12 & 14.56 & 16.38 \\
\hline Fruit weight & 94.67 & 14.56 & 15.89 & 26.95 & 39.24 \\
\hline Length of Fruit Peduncle & 99.67 & 26.95 & 43.8 & 16.14 & 13.32 \\
\hline Leaf width & 97.5 & 16.14 & -4.42 & -4.09 & -2.71 \\
\hline Leaf length & 94.68 & -4.09 & -11.42 & 3.55 \\
\hline Plant height & 97.55 & 0.35 & 8.31 & 0.35 & -21.02 \\
\hline Shoot length & 94.16 & -24.15 & 7.89 & -24.15 & -20.13 \\
\hline Shoot width & 92.6 & -18.07 & -1.79 & -18.07 & -18.63 \\
\hline Shoot area & 89.12 & -18.59 & -0.23 & -18.59 & -35 \\
\hline TOTAL GAIN & 93.75 & -33.39 & -4.6 & -33.39 & -35.56 \\
\hline - & - & 76.86 & 84.86 & 76.86 & 101.14 \\
\hline
\end{tabular}

IBW: Base Index - Willians (1962); IBGDPB: Index based on Desired Earnings - Pesek and Baker (1969); ICSH: Classic Index - Smith (1936) and Hazel (1943); IBSRMM: Index based on Sum of Ranks - Mulamba \& Mock (1978).

The highest genetic gains predicted by the Base Index (WILLIANS, 1962), from a total of $76.86 \%$, were $26.95 \%$ for the variable fruit weight and $123.17 \%$ for fruit length. On the other hand, the lowest predicted gains were $0.35 \%$ for leaf length, $14.56 \%$ for plant length and 16.14 for length of the petiole. The predict genetic gains of the characteristics leaf length was $-4.09 \%$, plant height was $-24.15 \%$, shoot length was $-18.07 \%$, shoot weight was $-18.59 \%$ and shoot area was-33.39\%. The meaning of negative genetic gain indicates that the selection of these characteristics will result in their reduction. The selection of peppers based on this index would result in plants with width fruits and peduncles, fruits with higher weight, leaves and petioles with greater length, and with a reduction of the other characteristics, resulting in plants with compact shoot and reduced size, which are desirable characteristics for ornamental plants. According to the Base Index (WILLIANS, 1962), 11 accessions were selected: UNEMAT 46; UNEMAT 21; UNEMAT 30; UNEMAT 15; UNEMAT 49; UNEMAT 27; UNEMAT 20; UNEMAT 5; UNEMAT 42; UNEMAT 25; UNEMAT 34, out of 55 accessions evaluated.

The genetic gains predicted by the Index-based Desired Earnings (PESEK and BAKER, 1969) method, out of a total of $84.86 \%$, the highest gains were $14.39 \%$ for fruit length, $11.42 \%$ for leaf weight, $15.89 \%$ for fruit weight and $43.8 \%$ for length of the petiole. The lowest predicted gains were $7.89 \%$ for plant height, $8.12 \%$ for plant length and
$8.31 \%$ for leaf length. The characteristics with negative genetic gains were leaf weight with $-0.23 \%$, shoot length with $-1.79 \%$, shoot area with $-4.60 \%$ and fruit length with $-18.34 \%$, thus the selection in these characteristics will result on their reduction. The selection based on this index would result in fruits with a larger diameter and weight, long peduncles, heavier fruits, larger leaves, higher plants and the reduction of the other characteristics evaluated. This index would not be advantageous due to plant high size, which is not desirable in ornamental plants. According to the Earned Earnings Index (PESEK and BAKER, 1969), 11 accessions were selected: UNEMAT 31, UNEMAT 32, UNEMAT 33, UNEMAT 41, UNEMAT 26, UNEMAT 42, UNEMAT 11, UNEMAT 24, UNEMAT 50, UNEMAT 12, and UNEMAT 5, out of 55 accessions evaluated.

The genetic gains predicted by the Classic Index of Smith (1936) and Hazel (1943), from a total of $76.86 \%$, the greatest predicted genetic gain was $123.17 \%$ for fruit length. The lowest predicted genetic gains were $0.35 \%$ for leaf length, $14.56 \%$ for plant length, $16.95 \%$ for length of the petiole, and $26.95 \%$ for fruit weight. The characteristics with negative genetic gains were fruit length with $-6.02 \%$, shoot length with $-18.07 \%$, shoot weight with -18.59 , plant height with $-24.15 \%$ and shoot area with $-33.39 \%$. The selection in these characteristics will result in their reduction. The selection based on this index would result in plants with long fruits and peduncles, fruits with higher weight, leaves and petioles with greater length, and the 
reduction of other characteristics. The selection would result in compact shoot and reduced size plants, as well as in the Base Index (WILLIANS, 1962), which are desirable characteristics for ornamental plants. According to Classic Index (SMITH, 1936; HAZEL, 1943), 11 accessions were selected: UNEMAT 46, UNEMAT 21, UNEMAT 30, UNEMAT 15, UNEMAT 27, UNEMAT 5, UNEMAT 20, UNEMAT 49, UNEMAT 25, UNEMAT 42, and UNEMAT 34 , out of 55 accessions evaluated.

The genetic gains predicted by the Summa RankBased Index method (MULAMBA and MOCK, 1978), from a total of $101.14 \%$, the greatest predicted gains were of $39.24 \%$ for fruit weight and $125.36 \%$ for fruit length. The lowest predicted gains were $1.34 \%$ for fruit diameter, $3.55 \%$ for leaf length, $13.32 \%$ for leaf petiole and $16.38 \%$ for peduncle length. The characteristics with negative genetic gains were leaf width with $-2.71 \%$, plant height with -21.02 , shoot length $-20.13 \%$, shoot width $-18.63 \%$ and shoot area with $-35.56 \%$. The selection in these characteristics will result in their reduction. The selection based on this index would result in plants with long fruits and peduncles, fruits with greater weight and wider, leaves and petioles with greater length, and the reduction of the other characteristics. The selection would result in compact shoot and reduced size plants, as well as in the Base Index (WILLIANS, 1962) and the Classic Index (SMITH, 1936; HAZEL, 1943), which are desirable characteristics for ornamental plants. According to the Index Based on Sum of Ranks (MULAMBA and MOCK, 1978), 11 accessions were selected, being: UNEMAT 46; UNEMAT 15; UNEMAT 21; UNEMAT 30; UNEMAT 5; UNEMAT 49; UNEMAT 42; UNEMAT 25; UNEMAT 20; UNEMAT 27; UNEMAT 8, out of accessions evaluated.

The indexes of selection evaluation showed that the Summa Rank-Based Index method (MULAMBA and MOCK, 1978) allowed to reach greater predicted gains among the indexes used in the present study. The other indexes also provided great selection of gains; however, the Earned Earnings Based Index (PESEK and BAKER, 1969), provided a positive gain for the variable plant height, which is not desirable for ornamental plants. Plants with reduced size are the main objective of genetic improvement programs for ornamental peppers. The Base Index, (WILLIANS, 1962) and the Classic Index (SMITH, 1936; HAZEL, 1943) showed equal totals values of the selection indexes $(76.86 \%)$, consequently, the use of these indexes will result on similar gains in the studied variables.

Comparing the selected accesses through the selection of indexes, we observed that there are similarity among the indexes, except for Earned Earnings Based Index (PESEK and BAKER, 1969), which had the accesses UNEMAT 42 and UNEMAT 5 in common to the others indexes. The access UNEMAT 8 was only selected by the Summa Rank-
Based Index method (MULAMBA and MOCK, 1978). All the other access was selected by all indexes but with different selection order. The analyses of several selection indices in a yellow passion fruit population structured in an I Design, Gonçalves et al. (2007) obtained the best genotypic predicted gain with the Summa Rank-Based Index method (MULAMBA and MOCK, 1978). The observed gains by the authors were $15.85 \%$ for number of fruits per plant, $0.82 \%$ for fruit weight, $0.35 \%$ for fruit length, $0.77 \%$ for fruit width and $1.55 \%$ for fruit peel thickness. Santos et al. (2008) evaluated the vigor and resistance to scabin yellow passion fruit and obtained genetic gains for both characteristics of approximately $10 \%$, using the same selection index. Silva et al. (2009), using the Summa RankBased Index method (MULAMBA and MOCK, 1978) in 26 half-sib progenies of yellow passion fruit, observed the predicted genetic gains of $3.18 \%$ for fruit weight, $0.47 \%$ for fruit length, $1.36 \%$ for fruit width and $0.65 \%$ for fruit peel thickness. Oliveira et al. (2008), when evaluating 16 half-sib progenies, obtained positive gains for all characters by direct selection, ranging from $2.5 \%$ for fruit format to $27.58 \%$ for number of fruits, and $11.33 \%$ for pulp productivity.

\section{CONCLUSIONS}

The Summa Rank-Based Index method Mulambaand Mock allowed to achieve a greater gain among the used indexes. According to the Summa Rank-Based Index method Mulamba and Mock, 11 accessions were selected: UNEMAT 46; UNEMAT 15; UNEMAT 21; UNEMAT 30; UNEMAT 5; UNEMAT 49; UNEMAT 42; UNEMAT 25; UNEMAT 20; UNEMAT 27; UNEMAT 8, out of 55 accessions evaluated.

\section{ACKNOWLEDGEMENTS}

The authors are thankful to the Research Foundation of the State of Mato Grosso - FAPEMAT and Higher Education Personnel Improvement Coordination-CAPES.

\section{AUTHORS CONTRIBUTIONS}

P.B.L.: Conception of the work, Data analysis and interpretation, Drafting and Critical revision of the article, Final approval of the version to be published. A.A.B.S.: Conception or design of the work, Data collection, Data analysis and interpretation, Drafting the article. V.C.A.: Data collection, Data analysis and interpretation, Drafting the article. L.G.N.: Conception or design of the work, Data analysis and interpretation. A.R.T.: Data analysis and interpretation, Drafting and Critical revision of the article. 


\section{REFERENCES}

BIANCHI, P.A.; DUTRA, I.P.; MOULIN, M.M.; SANTOS, J.O.; SANTOS JÚNIOR, A.C. Morphological characterization and analysis of genetic variability among pepper accessions. Ciência Rural, v.46, n.7, p.1151-1157, 2016.

CARVALHO, S.I.C.; BIANCHETTI, L.B.; RIBEIRO, C.S.C.; LOPES, C.A. Pimentas do gênero Capsicum no Brasil. Brasília: Embrapa Hortaliças, 2006. 27p. (Documentos, 94).

CRUZ, C.D. Programa Genes: Análise multivariada e simulação. Viçosa: UFV, 2010. 175p.

FILGUEIRA, F.A.R. Novo Manual de Olericultura. Viçosa: UFV, 2005. 413p.

GONÇALVES, G.M.; VIANA, A.P.; BEZERRA NETO, F.V.; PEREIRA, M.G.; PEREIRA, T.N.S. Seleção e herdabilidade na predição de ganhos genéticos em maracujá-amarelo. Pesquisa Agropecuária Brasileira, v.42, p.193-198, 2007.

HAZEL, L.N. The genetic basic for constructing selection indexes. Bethesda: Genetics, 1943. 476p.

IPGRI. Descriptores para Capsicum (Capsicum spp). Roma: IPGRI, 1995. 51p.

ISLA. ISLA Sementes. Porto Alegre - RS. Disponível em: $<$ http://www.isla.com.br> Acesso em: 08 de Fevereiro de 2018.

MULAMBA, N.N.; MOCK, J.J. Improvement of yield potential of the Eto Blanco maize (Zea may L.) population by breeding for plant traits. Egyptian Journal of Genetics and Cytology, v.7, p. 40-51, 1978.

NEITZKE, R.S.; BARBIERI, R.L.; RODRIGUES, W.F.; CORREA, I.V.; CARVALHO, F.I.F. Dissimilaridade genética entre acessos de pimenta com potencial ornamental. Horticultura Brasileira, v.28, p.47-53, 2010.

OLIVEIRA,E.J.;SANTOS, V.S.;LIMA,D.S.;MACHADO, M.D.; LUCENA, R.S.; MOTTA, T.B.N.; CASTELLEN, M.S. Seleção em progênies de maracujazeiro-amarelo com base em índices multivariados. Pesquisa Agropecuária Brasileira, v.43, p.1543-1549, 2008.

PESEK, J.; BAKER, R.J. Desired improvement in relation to selected indices. Canadian Journal of Plant Sciences, v.49, p.803-804, 1969.
PINTO, C.M.F.; BARBOSA, J.M.; MESQUITA, D.Z; OLIVEIRA, F.; MAPELI, A.M.; SEGATTO, F.B.; BARBOSA, J.G. Produção e qualidade de pimentas ornamentais comestíveis cultivadas em recipientes de diferentes volumes. Revista Brasileira de Horticultura Ornamental, v.16, p.113-122, 2010.

SANTOS, C.E.M.; PISSIONI, L.L.M.; MORGADO, M.A.D.; CRUZ, C.D.; BRUCKNER, C.H. Estratégias de seleção em progênies de maracujazeiro-amarelo quanto ao vigor e incidência de verrugose. Revista Brasileira de Fruticultura, v.30, p.444-449, 2008.

SANTOS, R.M.C.; RÊGO, E.R.; FERREIRA, A.P.S.; NASCIMENTO, M.F.; NASCIMENTO, N.F.F.; COCA, G.C.; RÊGO, M.M.; BORÉM, A.; FINGER, F.L. Inhibition of Ethylene Actionby 1-MCP in Post-Production Ornamental Peppers, Acta Horticulturae, v.1060, p.49$53,2015$.

SILVA, M.G.M.; VIANA, A.P.; GONÇALVES, G.M.; AMARAL JÚNIOR, A.T.; PEREIRA, M.G. Seleção recorrente intrapopulacional no maracujazeiro amarelo: alternativa de capitalização de ganhos genéticos. Ciência e Agrotecnologia, v.33, p.170-176, 2009.

SMITH, H.F. A discriminant function for plant selection. Annals of Eugenics, v.7, p.240-250, 1936.

SOARES, R.R.; SILVA, H.W.; CANDIDO, W.S.; VALE, L.S.R. Correlations and path analysis for fruit yield in pepper lines (Capsicum chinense L.). Comunicata Scientiae, v.8, n.2, p.247-255, 2017.

SUDRÉ C.P.; RODRIGUES R.; RIVA E.M.; KARASAWA M.; AMARAL JÚNIOR A.T. Divergência genética entre acessos de pimenta e pimentão utilizando técnicas multivariadas. Horticultura Brasileira, v.23, p.22-27, 2005.

WILLIANS, J.S.The evolution of a selection index. Biometrics, v.18, p.375-393, 1962.

WITT, D. The chile pepper encyclopedia. New York: William Morrow and Company, 1999. 337p 